\title{
COVID-19 AND THE MANAGEMENT OF THE ECONOMY OF ODISHA
}

\author{
Sanjukta Das ${ }^{* 1}$ (iD), Saida Banoo ${ }^{2}$ \\ ${ }^{1}$ Associate Professor, P.G. Dept. of Economics, \& member of World Bank OHEPEE funded project \\ Centre for Excellence for Regional Development and Tribal Studies, Sambalpur University, Odisha, \\ India \\ 2 Ph.D. Research Scholar, P.G. Dept. of Economics, Sambalpur University, Odisha \& Lecturer in \\ Economics, D.S. College, Laida, Sambalpur, Odisha, India
}

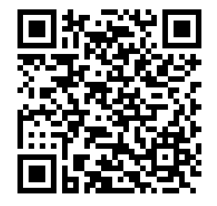

DOI: https://doi.org/10.29121/granthaalayah.v8.i9.2020.1543

Article Type: Research Article

Article Citation: Sanjukta Das, and Saida Banoo. (2020). COVID-19 AND THE MANAGEMENT OF THE ECONOMY OF ODISHA.

International Journal of Research GRANTHAALAYAH, 8(9), 277-282. https://doi.org/10.29121/granthaa layah.v8.i9.2020.1543

Received Date: 13 September 2020 Accepted Date: 30 September 2020

Keywords:

COVID-19

Management

Odisha

Economy

\begin{abstract}
Occurrence of COVID-19 pandemic and the policy measures taken from time to time to contain its spread have brought a huge loss to the economy. In this paper an attempt is made to analyse these by taking the case of Odisha which is one of the States in India that have taken proactive role in managing the COVID-19 related disaster. It discusses the Government policy of lock down in the country and Odisha. This is followed by an analysis of the effect of Lock down on the economy and livelihood. Then it tries to suggest some steps for managing the economy in this situation. Here it mainly emphasizes the local economy model for sustainable management of the economy.
\end{abstract}

\section{INTRODUCTION}

Since the declaration of countrywide Lock down in India due to the COVID-19 pandemic, in the month of March, 2020 Indian economy has been adversely suffering from the disruption of supply chain, low level of production of goods and services, unprecedented unemployment and declining livelihood opportunities, fall in the economic growth rate and above all a loss of confidence and incentives for private investment. In this paper an attempt is made to analyse how the economy and its people suffered due to the policy measures taken from time to time to contain the spread of COVID. For this we have taken the case of Odisha which is one of the States in India that have taken proactive role in managing the COVID-19 related disaster. It is also a state from where a large number of people move out to other places for earning their livelihood; some of them are intra-state and some are inter-state migrants; some migrate for short period and some for long period. Lock-down has adversely affected these workers. It is also a state where agriculture provides livelihood opportunities to the majority of its households. Lock down disrupted the farming operation for a quite long time and adversely affected the farmers and agricultural labourers. Besides agriculture, the trade, commerce and industries, construction activities suffered affecting people's livelihood. In this paper we also try to put forward some solutions for the sustainable management of the economy not only in the COVID ridden period but also in the future.

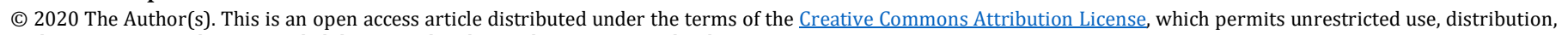
and reproduction in any medium, provided the original author and source are credited. 
Covid-19 and the Management of The Economy of Odisha

The paper is structured as follows: First it discusses the Government policy of lock down in the country and Odisha. This is followed by an analysis of the effect of Lock down on the economy and livelihood. Then it tries to suggest some steps for managing the economy in this situation. Here it mainly emphasizes the local economy model for sustainable management of the economy.

\section{GOVERNMENT POLICIES ON LOCKING AND UNLOCKING THE ECONOMY}

Odisha Government took early and pro-active steps to contain the spread of the Corona virus. Before the detection of any single positive COVID cases in the state, Odisha Government declared COVID-19 as a State disaster on $13^{\text {th }}$ March, 2020under the provision of State disaster Management Act, 2005 and declared closure of all educational institutions, swimming pools, cinema halls and asked people to avoid gathering for non-essential reasons. On $16^{\text {th }}$ March the first positive case was detected in the state. Central Government declared COVID-19 a national disaster only on $24^{\text {th }}$ April and put the whole nation in lock down mode for 21 days (i.e.25h March to $14^{\text {th }}$ April, 2020) which is known as the first phase of lock down and subsequently the lock down was extended of course with some changes. Prior to the lock-down declaration, on 22nd March Government of India declared the suspension of all passenger trains through 31 $1^{\text {st }}$ March. As on 10 $10^{\text {th }}$ April, 2020 the number of positive cases crossed 50, Odisha extended lock down to $31^{\text {st }}$ May. Subsequently the Prime Minister extended lock down for the whole nation up to $3^{\text {rd }}$ May which is known as the second phase. During this phase the districts were divided into red, orange and green zones depending on the basis of confirmed positive cases. A district was considered as red if infection cases are more, as orange if such cases are few in number and green if no case is found. In the red zone areas more restriction and in the other two zones less restrictions were imposed. Further on $1^{\text {st }}$ May Government of India extended lock down to $17^{\text {th }}$ May and this is known as the $3^{\text {rd }}$ phase of Lock down when more relaxations were introduced. Red, orange and green zones were redefined taking the number of confirmed cases and the period of doubling rate. Green zones were declared when no positive case is found in the last 21 days. Again fourth phase of Lock-down for the period from $18^{\text {th }}$ May to $31^{\text {st }}$ May was declared by the Central Government where the red zone was sub-divided into Containment zone and Buffer zone of which the former is meant for more restrictions. The local authority was given power to demarcate the containment and buffer zone. Later on in Odisha districts are classified as red, orange and green on the basis of Corona active cases: Districts with active cases more than 100 are categorized as red, with active cases of 51-100 as orange and active cases up to 50 are categoried as green. In this categorization a district's category changes depending upon the number of active positive cases ${ }^{1}$. Economy was allowed to open from $1^{\text {st }}$ June in phases (Unlock 1.0 from $1^{\text {st }}$ to $30^{\text {th }}$ June and Unlock 2.0 from $1^{\text {st }}$ to $31^{\text {st }}$ July and Unlock 3.0 from $1^{\text {st }}$ August to $31^{\text {st }}$ August where keeping only few restrictions economy was allowed to operate. It is said that this unlocking of the economy was done to promote economic activities.

Odisha Government has taken different measures as per the Government of India COVID-19 management guidelines. Accordingly complete lock downs were declared in districts like Jajpur, Bhadrak and Balasore in the month of April (23rd April, 2020) when more number of cases were found in these districts and again in the whole districts of Ganjam, Khorda, Cuttack, Jajpur and Rourkela Municipal Corporation from 17th July to 31st August, 2020. Similarly, District Collectors of different districts were empowered to declare complete shutdown of their respective districts/ district headquarters for some days observing the seriousness of the COVID situation. For example, Sambalpur Collector declared the lock down of Sambalpur District from 22 $2^{\text {nd }}$ July to 31 st July 2020. Of these 10 days, in the first four days even grocery and vegetables shops were not allowed to open. Similarly, Dhenkanal District Collector has declared shut down of the district on each Saturday and Sunday in the month of August. Like the District Collectors, the Sarpanch of each Panchayat was conferred upon District Collector Power by the Chief Minister for managing COVID in their areas. They were empowered to shut down their Panchayats/ different Wards observing the situation. This way Odisha has initiated a novel decentralization approach in managing the disaster.

${ }^{1}$ As on $30^{\text {th }}$ July 2020 out of the 30 districts of Odisha 22 are in the red category and both in the green and orange category four districts are found. 
Sanjukta Das, and Saida Banoo

\section{EFFECT OF LOCK DOWN ON THE ECONOMY}

Occurrence of COVID-19 pandemic and the policy measures taken from time to time to contain its spread have brought a huge loss to the economy. In the initial phase of the abrupt and complete lock-down of more than one month time period, all economic activities excluding the supply of essential commodities were almost stopped causing a huge loss to the producers, traders and workers. Farmers failed to harvest their Rabi crops. The present system does not provide insurance against this loss. Fishers, minor forest products collectors were not allowed to go outside their home for such collection. Mining and logging activities were also stopped. All types of construction works including those under even MGNREGS also stopped to break the chain of virus spread. People engaged in cottage industries were allowed to work at their home, but they failed to purchase/bring the raw-materials from outside and also could not sell their products. Their sufferings (income loss) were often telecast by different news channels in the television. All these people suffer from income loss; virtually they earned nothing. Except the vegetables, fruits and grocery sellers all other shop keepers were not allowed to open their shops. Restriction on trade and commerce disrupted the supply chain causing sometimes the scarcity/ abundances of some products. This influenced the prices and hence the income of the producers.

In the second phase of the lock-down economic activities such as agricultural works, construction and some other activities were allowed with certain guidelines to prevent the spread of the virus. Simultaneously during this period the stranded migrants were permitted to return to their own place through own/Govt arrangements by bus/train/any other means of transport including the simple walk on foot. By $7^{\text {th }}$ July as high as 3, 58, 401 inter-state passengers arrived Odisha by Shramik special trains and by $27^{\text {th }}$ July 2020, as high as 1,94,125 returned from other states by road as per Government of Odisha report. Together they account more than 5 lakh. Besides this, the cases of return of migrants through the porous border is also expected which if considered can raise the number of returnee migrants to at least six lakhs. The returnee migrants were made to stay in the local quarantine centres for 14 days arranged by the Government (state and local Governments). Non-migrant local persons are also kept in the quarantine centres when they are found in close contact with the Corona positive cases. In fact the quarantine centre stay of a person is considered a period under observation/detection of his/her possibility of Corona virus attack. After completing the quarantine period these people are permitted to go to their own houses. Initially the spread of COVID was mainly concentrated in the industrial states like Maharashtra, Gujarat, Delhi, Tamil Nadu but it became widespread all over the country by the mid of May. A good numbers of corona positive cases are found from the quarantine centres as well as from the local contacts as a result of which in those localities containment zones were declared for some days. In the containment zones few economic activities are permitted. When situation deteriorated in some towns/cities/ districts/states, authorities declared shut downs restricting most of the economic activities.

Realising the adverse effect of lock down on the economy Government is trying to unlock the economy partially in a phased manner with much caution. After unlocking when new positive cases are found very high, lockdown/shut down measures are resorted partially or fully examining the seriousness of the situations. This locking, unlocking and again locking down of the economies by the authority to control the disease has led to the rise in the frequency of locking down. This creates uncertainty for the producers and adversely affect their incentive to invest.

The increasing new positive cases and also the cumulative deaths due to COVID has become a challenge for the Government day by day and especially for the Department of Health. Predictions regarding the time period of the flattening of the COVID curve are revised from time to time. Reliable preventive vaccines are yet to come to the market and there is uncertainty regarding that. So is the case of medicine for this disease. As a result, the fear for Corona virus attack haunts the public's mind. But simultaneously the disruption of the normal functioning of the economy due to lock down declaration is also hounding the livelihood issue. Government's COVID time social security measures of advance supply (sometimes through home delivery) of free ration under PDS, and the provision of different allowances - to a certain extent saved the people from starvation. But these are not adequate for those whose economic activities were disrupted due to lock-down. The labourers especially working in the private sector as casual workers got the hardest hit. People's home containment minimized the income of the road side eateries, auto-rickshaw drivers, and public transport operators. Ban or restriction on the different social and religious functions deprived many people to earn their livelihood. Large number of micro entertainment units received the bolt from the blue. Closure of such large number of enterprises has resulted in huge unemployment and loss of income. Tourism sector was forced to become non-existent. This sector provides employment to approximately 4 
lakh workers directly and indirectly and causes inflow of funds worth of Rs 5000 crore approximately ${ }^{2}$. A rough estimate of loss of income worth of Rs 3000 crore and employment loss to at least 3 lakh persons may be assumed due to this lock down.

In the second phase of lock down Government tried to generate some employment under MGNREGS in rural areas and under Sahari Rojgar Yojana in the urban areas in which both the local and returnee migrant workers can be engaged. But all these works are to be undertaken by following the COVID-19 guidelines. Thus, in the unlock period the economy is also not able to operate smoothly causing loss of human hours, employment, income and output. Guidelines for the operation of work are imposing additional costs. Maintenance of social distance in workplace, use of masks and hand hygiene, reduction of operation hours/days through administrative orders are the examples of these. IT related service providing sectors were directed to engage their workers to work from home. But this abrupt switching to this work from home mode is expected to generate less output as the home environment is not ready enough to facilitate the work. Many people would lack adequate arrangements for facilitating the work from home. To avoid people's movement even the consumers of many services were encouraged to seek the services online. Online electricity bill payment, sending letters to different offices through email, electronic fund transfer, seeking medical service through telephone, online teaching, conducting lectures/seminars through webinar are the examples of such service seeking from home. However, such online service deliveries are not the good substitutes in case of a developing country like India. Off-line teaching at the institutions by the appointed teachers and at home/coaching centres by the private tutors is the better substitutes of on line teaching. Switching to online teaching also to a large extent at least initially will reduce the earning of the off-line private tutors. Regularly appointed teachers usually do not suffer from the loss of income, but the Guest faculty appointed as part-time teachers loses. The private home tutors, the caching institution owner, and his staff suffer from dwindled income. Similarly, to avoid the people's congregation sale through home delivery was permitted under the issued guidelines. But the sale and the profit from such sale in this way is expected to be less than the normal ones. Thus, all these give ample evidences of the fall in income and also the fall in the demand. This fall in demand in a recession economy ${ }^{3}$ is likely to further the recessionary tendency.

This low profit is likely to have adverse effect on investment. Further, the fear of shut down of the economy and the uncertainty of operation of the enterprises also discourage the private investment. Fall in investment is also expected to reduce the employment. Retrenchment of employees in the private sector is likely to come. Further the large number of returnee migrants also need employment opportunities in the absence of which they will be interested to migrate again. But in this pandemic situation by moving again they will be jumping from the frying pan to the fire. This implies the need for Government intervention to raise investment, to provide employment and to generate income. During Lock down phase 1 Government has requested the private employers not to evict their workers and not to cut their salaries. It has also supported all the public sector employees. But it has also incurred huge public spending to manage the COVID and to ensure the food security to its vast population. Under this situation to what extent it will be able to generate revenue and inject fund to maintain employment and raise income needs to be seen.

\section{STEPS FOR THE MACRO ECONOMIC MANAGEMENT}

Under this situation the following steps may be taken for macroeconomic management:

- To generate demand there should not be job cut especially of the low-paid contractual jobs as these job holders are expected to have high marginal propensity to consume. Low demand is likely to result in the reduction of employment by the private employers. So at least in the Government sector there should be job continuity and regular payment to the contractual /adhoc employees.

- Government must try to revive the existing sick industries such as Orissa Textile Mill, Choudwar, and other factories not only to create employment but also to use the returnee Odia migrants from places like Surat, Coimbatore.

\footnotetext{
${ }^{2}$ During 2010-11, a total number of 83,31,979 tourists (both domestic and foreign tourists) visited different places of Odisha and spent Rs 4,347.36 crore. The tourism sector has provided direct employment to 92,206 persons and indirect employment to 3,68,824 during the same period (Source: Department of Tourism and Culture as reported in Odisha State Profile-2013-14: page-12).

${ }^{3}$ Even before the occurrence of COVID-19, country was experiencing fall in the economic growth rate.
} 
- MSME promoting policy measures are necessary to transform the economy and to have high growth rate.

- Employment generation through higher spending on health and education especially on educating the people on health care etc. can help them to fight against different types of illness. Through ASHA and Anganwadi workers, different preventive measures of immunization and curative measures to many common curable diseases can be taken. This way healthcare and employment would go simultaneously.

- New sources of revenue may be in the form of either tax or surcharge can be thought of.

- Hike of holding tax on property may be thought of as this is not like to affect adversely the ability and willingness to work, save and invest. Rather it would bring more equity.

- Govt expenditure needs to be enhanced (i) to ensure food security and to avoid starvation death in the economy (ii) to provide health care support to the people affected by COVID as well as by other diseases.

- Government can resort to borrowing and at present should not worry much for the reduction of fiscal deficit.

\section{MANAGEMENT OF THE LOCAL ECONOMY}

Besides the management of the macro economy of the state there is also a need to manage the local economy. For this the following steps may be taken:

- In the migration prone Panchayats the skills of the migrants may be analysed and how to use those skills to generate employment and income in the locality may be considered. If possible Panchayat can think to invest for establishing such undertakings/ promote such investment through support. In some cases the youth of the Panchayat including the returnee migrants may be trained for some other semi-skilled jobs in the local undertakings. MSMEs may be encouraged in this context to make the rural economy vibrant.

- Panchayats may be given more autonomy (financial, administrative and management as well as Help of the relevant local NGO may be taken for educating and training the people of their local resource management) in the use/protection of local natural resources for creating sustainable livelihood. In this regard relevant technical assistance may be provided by the respective Govt. Departments such as Departments of Animal Husbandry, Horticulture, Fisheries, Forest and Environment, Agriculture etc. MGNREGS fund may be used to assist these endeavors.

- Further some radical innovative steps may be undertaken to promote economic growth with equity. A good amount of cultivable lands are kept fallow by the owner cultivators as they feel cultivation has become non-remunerative. Similarly a good amount of land is under oral tenancy where incentive for investment to raise productivity is low. To raise firm productivity Capitalist Contract farming is often suggested. The state Government has also passed an ordinance for promoting Contract Farming in Odisha. But if right institutions are created for joint management of Contract farming it can lead to equity. This will avoid the unutilisation/under-utilisation of land, the problem of moral hazard, help to reap the economies of large scale and simultaneously equity can be ensured. This way it can combine the benefits of contract farming as well as group operated farming of Kerala.

\section{CONCLUDING REMARKS}

COVID-19 is unprecedented and hence it is somehow difficult to predict correctly its duration, pervasiveness and adverse effect of the economy. However, the state can leave the economy to the market. It has to make positive interventions not only by using its fiscal policies but also by creating appropriate institutions for local economy management by the people in the neighbourhood.

\section{SOURCES OF FUNDING}

This research received no specific grant from any funding agency in the public, commercial, or not-for-profit sectors.

International Journal of Research -GRANTHAALAYAH 


\section{CONFLICT OF INTEREST}

The author have declared that no competing interests exist.

\section{ACKNOWLEDGMENT}

None.

\section{REFERENCES}

[1] Patnaik, P. (2016): A Perspective on Odisha's Recent Development Paradigm, The Economy of Odisha, Nayak, P.B., Panda S.C. and Pattanaik, P. K. Oxford University Press, New Delhi-110001, India, pp.497-517.

[2] Government of India (2014): Odisha State Profile, Ministry of Micro, Small and Medium Enterprises, Vikash Sadan, Cuttack-753003, MSME Development Organization.

[3] Government of India (2020): Government of India issues Orders prescribing lockdown for containment of COVID19 Epidemic in the country, Press India Bureau, 24th March.

[4] Government of India (2020): No. 40-3/2020- DM-I(A), North Block, New Delhi-110001, Ministry of Home Affairs, 15th April.

[5] Government of India (2020): No.1-29/2020 pp, NDMA Bhawan, A-1, Safdarjung Enclave, New Delhi-110029, National Disaster Management Authority Policy and Plan Division, 17th May.

[6] Government of India (2020): No. 40-3/2020- DM-I(A), North Block, New Delhi-110001, Ministry of Home Affairs, 30th May.

[7] Government of Odisha (2020): No. 4263/R\&DM (DM), RDM-RLF-MISC-0034-2020, Office of Special Relief Commissioner, 16th July.

[8] Office of The Collector and District Magistrate-Cum-Chairman (2020): No. 1015/ Emg., District Disaster Management Authority, Sambalpur, 20th July.

[9] Orissa Economic Association (2020): COVID-19 and The Economy of Odisha Challenges and The Way Forward, Bhubneswar, Odisha. 